\title{
THE IMPORTANCE OF BUSINESS CULTURE FOR INTERNATIONAL BUSINESS
}

\author{
Dijana Grahovac ${ }^{1}$ \\ Biljana Rađenović-Kozić²
}

DOI: https://doi.org/10.31410/LIMEN.2020.301

\begin{abstract}
In modern, global economic relations, interstate borders are minorized by the strong influence of economic interest. National business is becoming almost negligible because modern economic activities are, in most areas, within the framework of international business. Knowledge of the elements of culture in international business has become increasingly important, and it's reflected in the fact that it is necessary to know and respect the rules of the manner of business entities in certain cultures, which is both theoretically and practically confirmed as the only path that permanently provides long-term stability and successful business development in an international framework. For successful business cooperation with foreign partners, it is necessary to know their culture and how to adapt to it. Empirical researches in this area emphasize that depending on the culture business entities belong to, there are different business goals, relationships, different ways of business negotiation, business culture itself, and the values that come from it. Knowing and respecting diversity affects understanding and attitudes to (potential) business partners, which is the first step of business cooperation, and therefore has a significant impact on achieving positive results in negotiations in international business.
\end{abstract}

Keywords: Global economic relations, International business, Importance of different business cultures and values.

\section{INTRODUCTION}

$\mathrm{D}$ ifferences in religion, languages, cultural context, non-verbal communication, humor, giving, aesthetics, and many other areas, are significant and they can be a barrier in international business if they are not researched and accepted, respected, and incorporated into the strategy of going out to foreign markets. Basic knowledge of business style, work philosophy, and life of a potential partner helps to establish successful business relationships. A large number of researches were conducted in order to make the business more successful and they pointed out that depending on the culture to which managers belong, they have different business goals, relationships with the company, and others colleagues. Knowing and respecting dissimilarity affects the sympathy of business partners, which is also the first step of business cooperation; it is important to know the facts of the country you do business with and mainly refers to the full name of the state, capital of the state, name of the president of the state, it is useful to know the religion and religious customs, public and religious holidays, cultural differences in diet and similar.

University of Business Studies, Banja Luka, Bosnia and Herzegovina University of Business Studies, Banja Luka, Bosnia and Herzegovina 


\section{LITERATURE REVIEW}

Hofstede has developed five independent dimensions of national culture. He started by conducting research from 1967 to 1973 in two survey rounds initially regarding only four dimensions and produced answers to more than 116,000 questionnaires from 72 countries to examine country differences in values and attitudes. The initial analysis was limited to 40 countries, with more than 50 respondents each. In a later stage, data from 10 more countries and three multi-country regions were added (Hofstede, 2001. p. 41). When it comes to empirical research on the impact of culture on consumer choice in foreign markets, some international marketers have predicted a final convergence of culturally different markets into a "one world culture" that would facilitate standardized marketing activities. This, however, has turned out to be an illusion of too many hard factors, and cultural soft factors still exist or arise as constraints on international marketing that have to be dealt with continuously, utilizing various strategies of adaptation or localization.

The cultural value dimensions proposed by Hofstede have been extensively used in marketing and advertising literature to study cultural differences. This dimensional model provides country scores that can be used to analyze consumption and consumer behavior.

Marieke de Mooij applied his model to consumption-related values and motives. Mooij explained in her book "Global Marketing and Advertising" how appeals in advertising reflect the core values of culture. "Markets are people, not products. There may be global products, but there are no global people". Even though consumers of different countries use the same products, their motivations for buying products vary depending on their cultural differences.

Managers, researchers, and academics are exploring the potential of using the World Wide Web as a marketing tool. According to Singh et al, "web is not a culturally neutral medium". Therefore, website designers and advertisers must consider their audiences and respect cultural differences. When customizing a website to appeal to a different culture, it is not enough merely to translate the text.

\section{DOING BUSINESS IN GLOBAL TERMS}

If a term was chosen that symbolizes the spirit of today, it would be the term »globalization «. There is no precise or generally accepted understanding of the concept of globalization. Hopkins cites as the most acceptable, and probably the most neutral definition, the one according to which globalization is a process that rearranges (transforms) economic, political, social, and cultural relations between countries, regions, and entire continents while expanding, strengthening, and accelerating (Hopkins, 2002).

Globalization is a dynamic process that progresses, develops, and leads to unstoppable integration of national markets, states, and technologies, to the extent that has never been recorded in economic history (Jovancevic, 2005). According to the Oxford Dictionary of New Words, the meaning of the word is a consequence of the influence of Marshall McLuhan's thesis ${ }^{3}$ about the global village. Globalization is also defined as a "process of overcoming historically formed borders".

Herbert Marshall McLuhan (Edmonton, Alberta, Canada, 1911 - 1980) was a professor of English literature, a philosopher, a communication theorist and a literary critic. McLuhan can be considered the first theorist of media philosophy and the originator of the current that puts the problems of media and media mediation in the forefront of the research. McLuhan is best known for saying "media is the message" 
In the conditions of market globalization, the rapid development of technologies, and changing consumer requirements, new markets are opening up and creating greater opportunities for businesses to run multiculturally. Doing business in different cultures requires a new way of doing business and new strategic and tactical views.

\section{BUSINESS CULTURE}

The United Nations Educational, Scientific and Cultural Organization described culture as follows: "culture should be regarded as the set of distinctive spiritual, material, intellectual and emotional features of society or a social group, and that it encompasses, in addition to art and literature, lifestyles, ways of living together, value systems, traditions, and beliefs“".

Hall (1959) defines culture as the way of life of a people: the sum of their learned behavior patterns, attitudes and materials things. Culture is often subconscious; an invisible control mechanism operating in our thoughts (Hall, 1983). In his view, we become aware of it by exposure to a different culture. Members of a certain society internalize the cultural components of that society and act within the limits as set out by what is "culturally acceptable" (Hall, 1983, 230).

Culture consists of patterned ways of thinking, feeling, and acting, acquired and transmitted mainly by symbols, constituting the distinctive achievements of human groups, including their embodiments in artifacts; the essential core of culture consists of traditional (i.e. historically derived and selected) ideas and especially their attached values.

In the marketing literature, culture has been predominantly measured by cultural values. A value is defined by Rokeach, as an enduring belief that one mode of conduct or end-state of existence is preferable to an opposing mode of conduct or end-state of existence. Values are often measured on polar scales, for example; active versus passive, modern versus traditional.

Specific cultural variables, such as common beliefs, values, and attitudes determine basic attitudes of value towards the notions of time and materialism, as well as attitudes in relation to change, individualism, work experience and thus significantly affect the business planning and decision making (Radić, 2008).

A key impetus in the development of the study of cultural influences on organizations was represented by the mentioned research of Hofstede conducted in the period from 1967 to 1973 on a sample that included more than 116,000 respondents in the forty national branches of the multinational company IBM. The basic notion - the notion of Hofstede culture (Hofstede, 2001) is defined as "collective mind programming that distinguishes members of one group or category of people from another." Researches have shown that national culture has a greater impact on employees than organizational culture, so for example, German workers at IBM in Germany will be more influenced by German culture than the corporate culture of the company (Robbins, 2005).

and for the term "global village". He also predicted the Internet and the World Wide Web thirty years before its discovery. In the 1960s, he was at the height of his fame, and quickly forgotten after his death. But, with the advent of the internet McLuhan emerges from oblivion and interest in his work reappears. 


\section{BUSINESS COMMUNICATION AND BUSINESS NEGOTIATION}

Negotiation is constantly present in everyday life, and according to some theorists represents one of the skills needed for survival (Gosselin, 2007: 100). That is especially expressed in the business environment. The Latin root of the word negotiatus means "to do business", whence the present-day word in Spanish negocio comes from, which means "business". The golden rule of negotiation is: People will not negotiate with you if they do not believe that you can help them or if they believe that you can harm them (Sharpe, 1990., 21).

According to Stephen Cohen (Cohen, 2002: 3) "negotiation is a process in which two or more parties work together to reach a mutually acceptable solution to one or more issues, such as a commercial transaction, contract or agreement of any kind." International business negotiation is significantly different from negotiation in the domestic environment and requires different and extended knowledge on various issues.

According to Salacuse, "doing business in your country is about the same attitude towards international business as the domestic policy of the country with international diplomacy." (Salacuse, 1991: 252) For international business negotiations to be successfully led in the direction of achieving the desired goals, it is necessary to know well the conditions and the partner with whom negotiations are conducted. It requires knowledge on not only the job but also negotiating environment, partner culture that is extremely important for the course and outcome of negotiations, ideology, foreign partner bureaucracy, foreign government regime, environment, etc.

The complexity of international negotiations and business is equally pronounced with partners from different business environments. The origin of both partners has a great influence, if they are culturally closer and closer to civilization, the more likely it is to lead negotiations successfully. On the other hand, in the case of significantly different partners in cultural and business ways, it is necessary to implement detailed activities to get to know the partner and his culture before the negotiations. Differences in religion, languages, cultural context, nonverbal communication, humor, giving, aesthetics, and many other areas, are significant and they can be a barrier in international business if they are not researched and accepted, respected, and incorporated into the strategy. In global business, the differences between cultures create great difficulties in the negotiation process. Differences in the negotiation process from country to country include: (Deresky, 2003:158)

- Course and duration of preparation for negotiations,

- The relative importance of specific issues in relation to interpersonal relationships,

- The importance of general principles about specific problems,

- The number of people in the negotiating team and their position.

\section{CASE STUDY}

As already mentioned, national culture is a significant determinant of business success in the foreign market.

During their appearance on the international market, many companies faced initial failures due to insufficient knowledge of the cultural elements of the target markets. Some examples are: (Rakita 2003: 180)

- American Airline in Brazil promoted rendezvous lounges in their planes, which in Portuguese had the unpopular meaning of a room rented in a brothel. 
- In many regions of Southeast Asia, nibbling nuts is an elite habit, and black teeth a matter of prestige. Pepsodent's promise of white teeth through the message "Wonder where the yellow went" was considered a failure.

- The Mc Donell Douglas Corporation printed a brochure with its plane, intended for users in India, showing a man with a turban. The Indians kindly thanked, emphasizing that the turban is characteristic of Iran, not India.

- Pepsi Cola Co. once published an ad in the Taiwanese edition of Reader's Digest, with the slogan "Come alive with Pepsi!". But in Taiwan, it was associated with the return of ancestors from the dead, and in Germany to rise from the grave.

- When Kentucky Fried Chicken used his well-known slogan in Iran - "It's finger-licking good" (It is so good to lick your fingers) in the local language it had quite a different meaning (It's so good to eat your fingers).

- General Motors dealers in Puerto Rico were not happy with the name "Chevrolet Nova" because "nova" in Spanish means that something isn't going well. Then very quickly the name was changed in "Caribe" by G.M.

- Microsoft and Telefonos de Mexico have joined forces in the Mexican market to launch a new internet portal in Spanish www.tlmsn.com. However, Microsoft faced the problem with the online dictionary. When alternatives to the word "an Indian" are requested, the thesaurus generated the terms cannibal and savage. In Mexico most of the population is of indigenous origin and that caused resistance among users, because it has been politically incorrect. "I see this as very much dangerous because respect for our pride as Mexicans and our native roots lacks" said Adriana Luna, a Mexican congresswoman. One representative called the dictionary "fascist and conservative." For Microsoft, it meant a downfall in public relations.

Due to all the above, in international marketing special attention is paid to a thorough translation of the slogans or messages into the local language. The basic problem with translation is to keep the meaning and significance of the message.

Wrong translations can sometimes ruin even the best products or business ventures. It is possible to make cardinal mistakes when translating an advertisement from one language to another (Cateora 2002:491):

- Use of homonyms, that is words that have the same or similar form with different meanings. E.g., Irish Mist liqueur has been translated into German as Irischer Mist. "Mist" in English means haze, and in German cow dung. Rolls Royce changed the name of his model "Silver Mist" to "Silver Shadow" - before entering the German market.

- A literal translation that does not convey the intended meaning, e.g., an inscription in one Swiss restaurant "Our wines leave you nothing to hope for", which means "You don't have what to hope for when you drink our wines."

- Use of a symbol, e.g., an owl shown in an advertisement in India, where it is a symbol of misfortune.

- Unintentional message. An example is an ad that should provide easier "reading" in underdeveloped countries, because it was made in the form of a comic strip with three pictures - dirty clothes on the left picture, then soap and in the end clean clothes. But what an idea got consumers in Arab countries that read from right to left?

International business negotiation is significantly different from domestic negotiation environment and requires a diverse and expanded knowledge of various issues. According to 
Salacuse, "Doing business in your country is about the same as international business and the domestic politics of a country with international diplomacy".

Some cultures start from general principles when negotiating, while others deal with individual problems. The speed of negotiations and decision-making styles also differ in different cultures, as well as making a concession. Researches have shown that reciprocity of concessions is more important in individualistic cultures (e.g., the USA) than in collectivist ones (e.g., Vietnam). Namely, negotiators from collectivist countries largely cooperate with other parties, regardless of the behavior of the opposing negotiator, while for individualists it is important the behavior of the other party (Parks, 1998). Of course, generalization should be avoided, because not all individuals follow cultural stereotypes.

Parochialism and stereotypes are two major dangers in international negotiating. Parochialism refers to the notion that due to globalization all business people behave similarly (mostly on the American model). This leads to stereotypes, and that is generalizations about any nation or state. Positive and negative stereotypes will have the opposite influence on the negotiation process. For example, due to negative stereotypes of the company, an exporter may require a low-risk billing method, such as a letter of credit (Czinkota, \& Ronkainen, 2004).

In Graham's research (1985), based on the classification of the various units, percentages of each bargaining category were calculated for each participant, for each negotiation. These findings are summarized in Table 1. As the data indicate, the percentages of each category are surprisingly consistent across 3 groups. The only substantial discrepancies are that the Brazilians appear to make fewer promises and commitments and more commands than either the American or Japanese business people.

Theory suggests that the process of marketing negotiations differs across cultures. More specifically, this author (1980) reported that the "pattern" of interaction in Japanese sales negotiations differs from that of American sales negotiations. Pattern here is defined as a timeordered sequence of events. One way to view the "pattern" of interaction is through the perspective of content analysis - the various bargaining behaviors being the "specific events" referred to above. The summary data presented in Table 1 provides some information about the pattern.

Table 1. Behavior during negotiations: Japan, USA, and Brazil - percentages of each bargaining category

\begin{tabular}{|l|c|c|c|}
\hline Bargaining Behaviors and Definition & Japan & USA & Brazil \\
\hline $\begin{array}{l}\text { Promise. A statement in which the source indicated his } \\
\text { intention to provide the target with a reinforcing consequence } \\
\text { which source that anticipates target will evaluate as pleasant, } \\
\text { positive, or rewarding }\end{array}$ & 7 & 3 \\
\hline $\begin{array}{l}\text { Threat. Same as a promise, except that the reinforcing } \\
\text { consequences are thought to be noxious, unpleasant, or } \\
\text { punishing. }\end{array}$ & 4 & 4 & 2 \\
\hline $\begin{array}{l}\text { Recommendation. A statement in which the source predicts } \\
\text { that a pleasant environmental consequence will occur to the } \\
\text { target. Its occurrence is not under the source's control. }\end{array}$ & 7 & 4 & 5 \\
\hline $\begin{array}{l}\text { Warning. Same as a recommendation, except that the } \\
\text { consequences are thought to be unpleasant. }\end{array}$ & 2 & 2 & 1 \\
\hline $\begin{array}{l}\text { Reward. A statement by the source that is thought to create } \\
\text { pleasant consequences for the target. }\end{array}$ & 1 & 3 & 2 \\
\hline $\begin{array}{l}\text { Punishment. Same as a reward, except that the consequences } \\
\text { are thought to be unpleasant. }\end{array}$ & 1 & 3 \\
\hline
\end{tabular}




\begin{tabular}{|l|c|c|c|}
\hline $\begin{array}{l}\text { Positive normative appeal. A statement in which the source } \\
\text { indicates that the target's past, present, or future behavior was } \\
\text { or will be in conformity with social norms. }\end{array}$ & 1 & 1 & 0 \\
\hline $\begin{array}{l}\text { Negative normative appeal. Same as positive normative } \\
\text { appeal, except that the target's behavior violates social norms. }\end{array}$ & 3 & 1 & 1 \\
\hline $\begin{array}{l}\text { Commitment. A statement by the source to the effect that its } \\
\text { future bids will not go below or above a certain level. }\end{array}$ & 15 & 13 & 8 \\
\hline $\begin{array}{l}\text { Self-Disclosure. A statement in which the source reveals } \\
\text { information about itself. }\end{array}$ & 34 & 20 & 39 \\
\hline $\begin{array}{l}\text { Question. A statement in which the source asks the target to } \\
\text { reveal information about itself. }\end{array}$ & 20 & 6 & 14 \\
\hline $\begin{array}{l}\text { Command. A statement in which the source suggests that the } \\
\text { target performs a certain behavior. }\end{array}$ & 8 & 22 \\
\hline
\end{tabular}

Source: Graham J. L. (1985) "The Influence of Culture on the Process of Business Negotiations: An Exploratory Study“, Journal of International Business Studies, Spring 85, Vol. 16, Issue 1, p. 88

Elements of non-verbal communication are also a very important segment of any culture and they are expressed through cross-cultural differences (table 2).

Table 2. Differences in the interpretation of non-verbal communication (Rakita 2003:194)

\begin{tabular}{|c|c|c|}
\hline Non-verbal Behavior & Country & Meaning \\
\hline Outstretched thumb & $\begin{array}{l}\text { USA } \\
\text { Middle East, } \\
\text { Japan, } \\
\text { Germany }\end{array}$ & OK/gesture of approval \\
\hline A finger circling the ear & $\begin{array}{l}\text { Argentina } \\
\text { USA }\end{array}$ & $\begin{array}{l}\text { Phone } \\
\text { "That's silly", }\end{array}$ \\
\hline Waving a raised hand & $\begin{array}{l}\text { USA } \\
\text { India, } \\
\text { South } \\
\text { America } \\
\text { Europe }\end{array}$ & $\begin{array}{l}\text { "Goodbye" } \\
\text { Summoning } \\
\text { Sign "NO", }\end{array}$ \\
\hline $\begin{array}{l}\text { A circle formed by the index } \\
\text { finger and thumb }\end{array}$ & $\begin{array}{l}\text { USA } \\
\text { Turkey }\end{array}$ & $\begin{array}{l}\text { "Very good" } \\
\text { Offensive sign / Homosexuality }\end{array}$ \\
\hline Crossing the first two fingers & $\begin{array}{l}\text { USA } \\
\text { Taiwan }\end{array}$ & $\begin{array}{l}\text { Good luck } \\
\text { No smoking }\end{array}$ \\
\hline Eye contact & $\begin{array}{l}\text { USA } \\
\text { Japan } \\
\text { Asian States } \\
\end{array}$ & $\begin{array}{l}\text { A sign of showing interest } \\
\text { Bad attack on privacy } \\
\text { Disrespect for the elderly }\end{array}$ \\
\hline Spreading the eyes & $\begin{array}{l}\text { USA } \\
\text { China } \\
\text { Latin America } \\
\end{array}$ & $\begin{array}{l}\text { Surprise } \\
\text { Anger } \\
\text { Request for help }\end{array}$ \\
\hline Nodding head left and right & $\begin{array}{l}\text { West } \\
\text { countries } \\
\text { Bulgaria } \\
\end{array}$ & $\begin{array}{l}\text { Sign of disagreement - NO } \\
\text { Stacking sign - YES }\end{array}$ \\
\hline Nodding head up and down & $\begin{array}{l}\text { West } \\
\text { countries } \\
\text { Greece and } \\
\text { Bulgaria }\end{array}$ & $\begin{array}{l}\text { Stacking sign - YES } \\
\text { Sign of disagreement - NO }\end{array}$ \\
\hline
\end{tabular}


Differences in culture and philosophy between countries have led to differences in negotiation styles. Below is a model, established by Deresky, describing several variables impacting crosscultural negotiation. The differences in style as a consequence of these different variables should be noted when considering some of the distinctions made between the different counties in later sections.

Graph 1. Variables that have an impact on cross-cultural negotiation

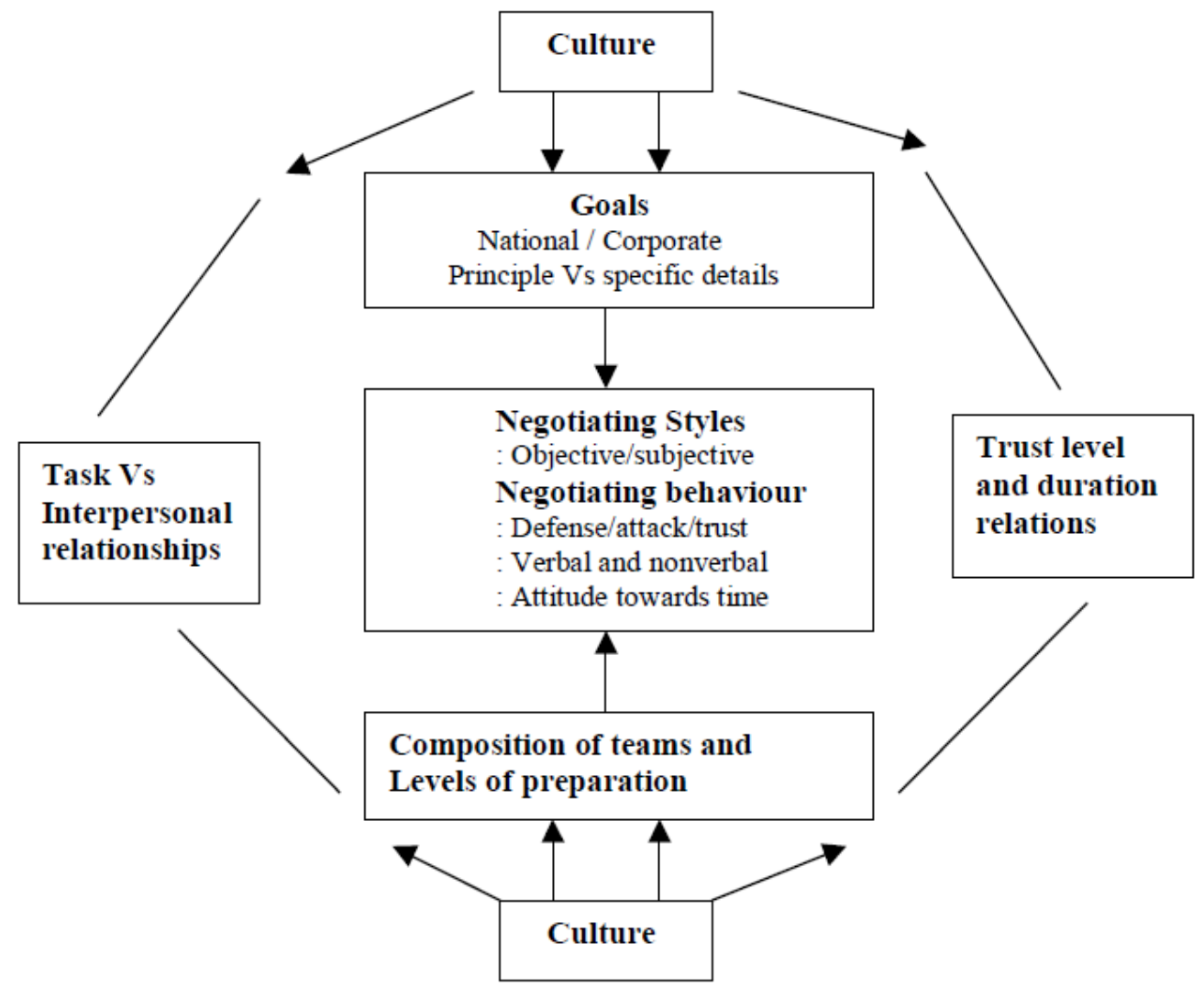

Source: Deresky, H. (2003) International Management - Managing Across Borders and Cultures, Prentice-Hall, Upper Saddle River, New Jersey, p. 173

Negotiation style is influenced by the attitudes, expectations, and usual behavior of negotiators. Czinkota \& Ronkainen (2004) highlight the following points in which the manager should modify his style during negotiating with foreigners:

- Team support. The team should have specialists in various fields so that the problems can be seen from all sides. For inexperienced team members, observation of experienced colleagues during negotiations would be welcome. Besides, even when there are disagreements between team members, it is very important to solve them in a closed circle, and in front of strangers to show agreement.

- Tradition and customs. It is necessary to use the services of local representatives in order to negotiators become familiar with the business procedures and status of the opposing team. It is desirable to use informal means of communication to find out the status of the title of those with whom it will be negotiated. Even the simplest rituals can be a problem, e.g., it is common in Asia for the first business meeting to end with the exchange of business cards which must have translated text on one side into the host language. They are given with both hands.

- Language skills. Ideally, the negotiator should speak the language of a host, but this is not always possible. As part of the negotiating team, it is mandatory the presence of a 
qualified translator, who also knows the culture of the host well, so that nothing would be lost in translation from a linguistic or cultural point of view. Using the translator also allows the negotiator longer to think. In a speech, jargon and idiomatic phrases should be avoided.

- Determination of authority. It is expected from negotiators from Europe and North America to have full decision-making authority when negotiating in the Far East, although no one from the opposing team has one. Acknowledgment that none of the teams has the final word in the decision-making process can negatively affect the negotiation process, but sometimes it is used as a tactic to get a better insight into the intentions of the opposing team. In Russia, a foreign negotiator must be certain who has the final word in the negotiations - the central or local government.

- Patience. In many countries, such as China, negotiations can take up to three times longer than in Europe and the United States. In Brazil and Thailand, showing impatience may only prolong negotiations instead of speeding it up.

- Negotiating ethics. Attitudes and values differ between cultures. Somewhere cunning is valued, and somewhere it is not. For example, negotiators from the West often remain confused by Russians' requests for last-minute concessions.

- Silence. Negotiators must properly understand every type of communication, even silence, although for Americans it is a negative sign. For example, Finns sit during a meeting without movement, without facial expression. In that way Finns generally show respect for the speaker, listening to him carefully.

- Persistence. Insisting on agreement and results is considered in some cultures a threat because they see negotiations as establishing long-term relationships, not as an event with winners and losers.

- Holistic approach. Concessions should be avoided until the end of the negotiations, especially when it talks about prices. If the price is agreed upon too early, the other party may insist that too many things are included in that price.

- Meaning of agreement. What the final agreement consists of will depend on the culture. Contrary to the importance of the contract for the Americans, for the Chinese, it is just a work plan for developing relationships in the future.

\section{COMPARATIVE ANALYSIS}

From all the above, it can be concluded that every appearance on the international market must follow all the elements of national culture. Basic cultural values determine the way of presenting information, whether and when concessions are made, the general nature and duration of the relationship between the negotiating partners. However, certain styles that are common to several countries can be "pulled out", as well their comparison (table 3).

Table 3. Comparison of different negotiation styles

\begin{tabular}{|l|l|l|l|}
\hline Region/Style & North America & Arabs & Russians \\
\hline $\begin{array}{l}\text { Primary style and process } \\
\text { of decision-making }\end{array}$ & $\begin{array}{l}\text { Factual: } \\
\text { invoking logic }\end{array}$ & $\begin{array}{l}\text { Emotional: } \\
\text { invoking feelings }\end{array}$ & $\begin{array}{l}\text { Axiomatic: } \\
\text { invoking ideals }\end{array}$ \\
\hline $\begin{array}{l}\text { Way of response to the } \\
\text { contradictory arguments } \\
\text { of the opposite side: }\end{array}$ & Objective facts & Subjective facts & Proven ideals \\
\hline Making compromises & $\begin{array}{l}\text { Small compromises are } \\
\text { given early to slow } \\
\text { down the relationship }\end{array}$ & $\begin{array}{l}\text { Compromises are made } \\
\text { during negotiations as } \\
\text { part of the process }\end{array}$ & $\begin{array}{l}\text { It is done very few } \\
\text { compromises }\end{array}$ \\
\hline
\end{tabular}




\begin{tabular}{|l|l|l|l|}
\hline $\begin{array}{l}\text { Response to opponent's } \\
\text { compromises }\end{array}$ & $\begin{array}{l}\text { It is usually answered } \\
\text { with reciprocal } \\
\text { compromises }\end{array}$ & $\begin{array}{l}\text { Almost always } \\
\text { corresponds to reciprocal } \\
\text { compromises }\end{array}$ & $\begin{array}{l}\text { Compromises are } \\
\text { considered as the law of } \\
\text { weakness }\end{array}$ \\
\hline Relationship & Short-term & Long-term & $\begin{array}{l}\text { No permanent } \\
\text { relationship }\end{array}$ \\
\hline Authority & Wide & Wide & Limited \\
\hline Starting position & Moderate & Extreme & Extreme \\
\hline Adherence to deadlines & Very important & Relaxed & Ignored \\
\hline
\end{tabular}

Source: Glenn, E. S., Witmeyer, D., Stevenson, K. A. (1984) "Cultural Styles of Persuasion“, International Journal of Intercultural Relations, No. 1, taken from Deresky, H. (2003) International Management - Managing Across Borders and Cultures, Prentice-Hall, Upper Saddle River NJ, p. 168

\section{a. Doing business in Turkey}

The success of business negotiations in Turkey depends on trust and mutual relations between negotiators. The process of making important decisions is quite slow. It is unacceptable to put pressure and set deadlines because otherwise, they will threaten to break off negotiations and cancel business (Rumenčić, 2008: 236). The essence of negotiations is not always just profit, but honor is also important, influence and respect for others. Pride is the base of all relationships in the family, society, and country (Rumenčić, 2008: 238), persistence and bargaining are expected. Relation to time is flexible.

\section{b. Doing business with the Arabs}

Characteristics, features s and cultural customs, which are part of the business culture of this people, to a greater or lesser extent are based on the theological and theoretical bases of Islamic Sharia (religion) (Veselinov, 2008).

During business conversations with Arabs, it is common to shake hands at a meeting and parting, being late for a meeting is not considered rude, unpleasant topics (such as politics and religion) should be avoided as well as questions about private life, should not be sat down so that the soles of the shoes can be seen (this is considered as a great insult), meetings last a long time - impatience must not be shown.

Setting deadlines is considered rude, and jobs will be done once "when it is the will of Allah." The Arabs pay a lot of attention to hospitality, they are very polite with business partners and they try to prove themselves as good hosts.

The most unacceptable business action in the Arab business world is the interest rate (Rahman, 2010). Interest rate, by definition, represents the additional income that the lender requires from the borrower. Islam forbids all kinds of interest for the reason that it implies oppression and exploitation. A clear distinction is made between the original business profit (which is desirable) and interest (an undesirable form of acquisition).

Since the beginning of business negotiations, it is expected to generally discuss the history and background of the company, expectations, ways of achieving results, the expected profit, and the overall agreement, and to gradually introduce details related to the job itself (Patai, 2002). If the idea or business project is presented in such a way, Arabs will consider you a reliable and responsible business partner. 


\section{c. Doing business with the Japanese}

Japan's religious tradition embodied in Confucianism, Buddhism, and Shintoism is a remarkable basis for the acceptance of scientific and technical achievements because it is based on a high degree of education of people in Japan and it is the basis of Japanese culture.

The basics of Confucian Human Science and the essence of its moral base is reflected in the following principles: collectivism and cooperation \& desire for learning and cognition, whose basics are (Varley 2000):

- humanism (zen),

- sense of duties and obligations (ji),

- respect for the elderly (xiao).

Western culture values the principle of the superiority of the individual over the group. In Japanese culture, it's exactly the opposite. The loyalty of an individual to his immediate group is the highest, and not even own interests cannot be above the commitment to the welfare of the immediate community. Firmly advocating attitudes and not deviating from them, even in unimportant matters, in the West represents a strong personality.

The Japanese have the opposite. Ultimatum "either he or I" is completely incomprehensible to them. Managerial style and decision-making in Japanese companies emphasize the information flow and initiatives from lower structures to higher ones, making top management facilitator more than a source of authority, while middle management serves for shaping initiatives and additional stimulus. Basic rules of work code to the Japanese are: never do something that is the job of someone above you, never do anything that jeopardizes the status of others, and never jump over hierarchical barriers (Alston 2005).

\section{d. Doing business with the Chinese}

China is the country with the oldest civilization, which lasts over 6,000 years and is one of the most populous countries in the world. As such, it is rich in different ethnic and cultural heritage influenced by Confucianism and Taoism as dominant philosophical, ethical, and religious directions.

In the business culture of this country pride and honor is an extremely important factor. Both personal reputation and social position depend on it, and its loss would have severe business consequences (Flower, 2010). In Chinese business culture, collectivism is still represented, that's why the other party during the negotiations may have to make a presentation to different people at different levels of the company. It is good that the material for the presentation is black and white because different colors have different connotations to Chinese. The Chinese side will expect the meeting to be led by people at top positions in the company, and interrupting the speaker and breaking into the word is considered indecent (Wenier, 2007).

\section{CONCLUSION}

From everything presented in this paper, it can be concluded that respect for all elements of national culture is very important when entering a certain market. There has been strong evidence to suggest that understanding the behaviors, attitudes, values, beliefs, arts, and artifacts of the host country nationals is a key success factor for organizations operating in different countries. Managers working in different cultures have to explore and identify what 
is hidden in the behaviors and actions of people from different cultural backgrounds and value orientations.

There are no uniform rules, nor unique strategies are possible. Differences in cultures are expressed through different relationships to certain concepts, such as time, money, attitude to work, as well as interpretations of non-verbal communication. Also, language barriers are very pronounced, through which even large experienced multinational companies can experience failures, which is evident from the above examples. Therefore, different performance strategies are required, business and market communication, respecting all the differences of a particular culture, which primarily determines the behavior of both business partners and consumers in a particular market.

Knowing the characteristics of business culture and the way of negotiation is an essential precondition for the realization of successful cooperation with foreign partners, and thus appear on the foreign market. Only that way it is possible to achieve successful business cooperation, without the occurrence of any misunderstandings, which may affect the negative outcome of the negotiations. Good intercultural communication ensures dissemination and business development, as well as generating higher levels of profit.

\section{REFERENCES}

Alston, J. (2005). Japanese Business Culture and Practices: A Guide to Twenty-First Century Japanese Business, iUniverse, Inc.

Cateora, P. R. \& Graham, J. L. (2002). International Marketing, Eleventh Edition. Irwin McGraw-Hill

Cohen, S. (2002). Negotiating Skills for Managers. McGraw-Hill. Madison. Wisconsin.

Czinkota, M. \& Ronkainen, I. (2004) International Marketing, 7th Edition, Thomson SouthWestern, Mason, Ohio

Deresky, H. (2003). International Management-Managing Across Borders and Cultures. Prentice-Hall, Upper Saddle River, New Jersey

Flower, K. (2010). China - Culture Smart!. The Essential Guide to Customs \& Culture.

Gosselin, T. (2007). Practical Negotiating: Tools, Tactics and Techniques. John Wiley \&Soons

Graham J. L. (1985) "The Influence of Culture on the Process of Business Negotiations: An Exploratory Study“, Journal of International Business Studies, Spring 85, Vol. 16, Issue 1

Hall, E. (1959). The silent language. New York: Doubleday.

Hall, E. (1983). The dance of life: The other dimension of time. New York: Doubleday.

Hofstede G. (2001). Culture's Consequences, Thousand Ouks. CA: Sage Publications.

Hopkins, A.G., (2002). The History of Globalization - and the Globalization of History, A. G. Hopkins (ed.) Globalization in World History, Pimlico, Sydney

Jovančević, R., (2005). Economic Effects of Globalization and the European Union, Macron Traffic, Zagreb,

Parks, C.D., Komorita, S.S. (1998). Reciprocity Research and Its Implications for the

Negotiation Process, International Negotiation, Vol. 3, Issue 2

Patai, R. (2002). The Arab Mind. Hatherleigh Press.

Radić, R. (2008). Strategic Management. UPS, Banja Luka.

Rahman, A. Y. (2010). The Art of Islamic Banking and Finance. Wiley.

Rakita, B. (2003). International Marketing. Faculty of Economics, Belgrade.

Robbins, S. (2005). Essentials of Organizational Behavior, VIII ed., Pearson Prentice 
Rumenčić, N. (2008). Business Negotiations with Foreign Partners. Construction book.

Salacuse, J. (1991). Making Deals in Strange Places: A Beginner's Guide to International Business Negotiations, John Wiley \& Sons.

Sharpe, M., (1990), Harmonizing ethical values in the global village: The public relations professional challenge!, International Public Review, Tom 13

Varley, P. (2000). Japanese Culture. University of Hawaii Press.

Veselinov D.(2008). Islamic Political Economy. FPN, Belgrade.

Wenier, R. \& Eagan, A. (2007). Culture Shock! China: A Survival Guide to Customs and Etiquette, Marshall Cavendish Corp. 